(RESEARCH ARTICLE)

\title{
Ethnobotany and floristic study of medicinal plants used in the treatment of respiratory diseases in the industrial region (Arzew) Oran, Algeria
}

\author{
Bouredja Nadia*, Mekdad Hadjira and Baghdadi Khadra \\ Department of living and Environment, Faculty of Natural Science and Life, University of Sciences and Technology, \\ Mohamed Boudiaf-Oran, Algeria.
}

Publication history: Received on 10 September 2017; revised on 09 October 2017; accepted on 07 November 2017

https://doi.org/10.30574/gscbps.2017.1.2.0015

\begin{abstract}
The present study was carried out with the aim of making a complete inventory of medicinal plants and their therapeutic uses in the region of Arzew, Algeria using the series of ethnobotanical surveys. The survey targeted 500 people from the local population, of which 279 people use medicinal plants (56\%) and 151 people use modern medicine (30\%) and 70 people use both medicines (14.00\%). Thus, the survey identified 65 plant species belonging to 32 families, including the Lamiaceae, which are the majority, followed by Apiaceae and Fabaceae. The foliage is the most used part and the majority of the remedies; it is prepared in the form of decoction. This study highlights the medicinal plants used in the treatment of respiratory ailments with a rate of $40 \%$. The results obtained constitute a valuable source of information for the region studied and for the national medicinal flora. This could be a database for further research in the fields of phytochemistry and pharmacology and for the purpose of seeking new natural substances.
\end{abstract}

Keywords: Aromatic and medicinal plants; Arzew; Ethnobotanical study; Respiratory diseases; Traditional medicine; survey.

\section{Introduction}

Plants have always occupied a prominent place in the life of man. All known civilizations have used plants either wild or grown for food, defenses, clothing or healing. These uses have diversified over time to adapt to the needs. Today, and especially in Third World countries, phytotherapy still occupies an important place. The flora of these countries is certainly rich and promising, both from the perspective of discovering new botanical species and from finding new molecules with therapeutic activity, for the development of new drugs [1].

The use of medicinal plants for the treatment of diseases usually comes from the belief that they have very low toxicity due to their natural origin. According to the World Health Organization, around $80 \%$ of the world's population uses traditional medicine for health care [2].

Algeria is considered among the countries known for their taxonomic diversity due to its privileged biogeographical position and its extension between the Mediterranean and sub-Saharan Africa. The Algerian flora is potentially rich.We share with the Mediterranean and the Sahel countries a wide range of compounds and phytochemicals of growing interest, hence the necessity and importance of this research work. This brewing of species constitutes a real wealth for our country which must be preserved and managed rationally and sustainably in order to maintain the already fragile ecological balances and to conserve our biological diversity [3].

\footnotetext{
${ }^{*}$ Corresponding author

E-mail address: bouredjanadia2007@yahoo.fr
}

Copyright (C) 2017 Author(s) retain the copyright of this article. This article is published under the terms of the Creative Commons Attribution Liscense 4.0. 
The use of plants to cure diseases or phytotherapy, has been known since antiquity. Ibn Khaldun in his Introduction says that "man is the son of his environment", therefore man would be influenced by the components of his environment and this influence builds on his behaviors, his traditions his culture. The more man is obliged to use the techniques and resources existing around him to support himself. The present study was carried out with the aim of making a complete inventory of medicinal plants and their therapeutic uses in the region of Arzew, Algeria using the series of ethnobotanical surveys.

\section{Material and methods}

In order to ensure a high degree of objectivity of the data obtained from our study, the survey is carried out using an inquiry form or questionnaire [4]. This pre-established is articulated around four axes:

- Information about the profile of the informant (age, gender, level of study ...)

- Choice between the two medicines (modern and traditional)

- Information on the nature and pharmaceutical techniques of the plant drug used (local name, part used, method of preparation, dose, etc.)

- Information on the use of medicinal plants in the care of different types of diseases.

The survey interviewed 500 people of different ages, gender and intellectual levels. Who informed us about the therapeutic and traditional local applications of the population of the daïra of Arzew.

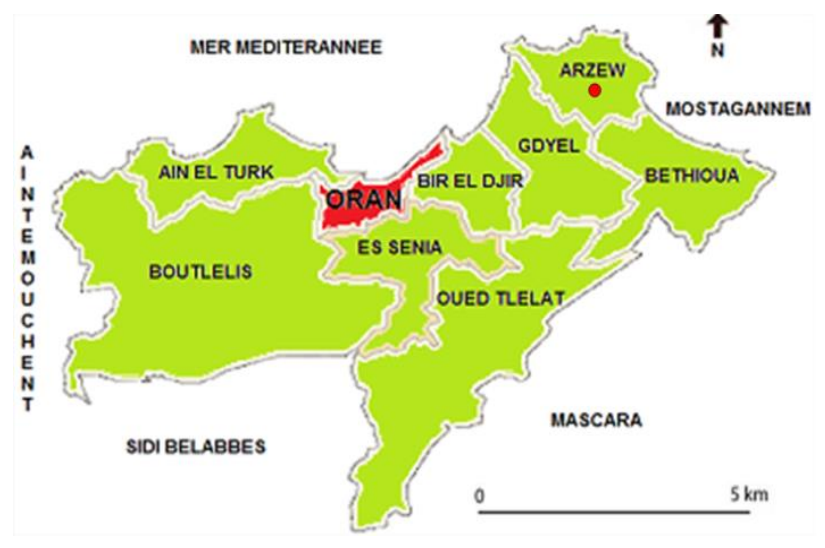

Figure 1 Study zone (Arzew)

\section{Results and discussion}

\subsection{Choice between traditional medicine and modern medicine}

The ethnobotanical survey carried out on the ground made it possible to interview 500 people including women and men, of whom 279 used traditional medicine (56\%) and 151 modern medicine (30\%) and 70 people used the two medicines $(14.00 \%)$.

\subsection{Use of medicinal plants according to the profile of the respondents}

\subsubsection{Depending on the genre}

In this region, users using traditional medicine are of the order of 279 people. In addition, men and women are concerned with traditional medicine. The $54 \%$ of users of medicinal plants are women and $46 \%$ of men.

\subsubsection{Depending on the age}

The use of medicinal plants in the Arzew dairy circle is widespread in all age groups, with a predominance among people aged 45 and over with a rate of $44.00 \%$, followed by the age groups of 30 to 45 with a rate of $37 \%$ and people of age between 18-30 years have a frequency of use of medicinal plants of $19 \%$. 
Knowledge of the properties and use of medicinal plants is generally acquired through experimental knowledge accumulated and transmitted from one generation to the next. Indeed, the results obtained show that people who belong to the age group above 45 years have more knowledge of medicinal plants compared to other age groups.

Experience accumulated with age is the main source of information. On the other hand, a loss of information on medicinal plants, explains the mistrust of some people, especially young people (18 to 30 years), who tend not to believe in this traditional medicine.

\subsubsection{Depending on the level of study}

Data processing allowed us to obtain the chart in Figure 4, which shows that $35 \%$ of people who use medicinal plants have a secondary level, and then come to university, primary and nil levels; with a percentage of $25 \%, 20 \%, 20 \%$.

\subsubsection{Depending on family situation}

Analyzes of the data show that medicinal plants are much more used by married people with a rate of $61 \%$ per contribution than single people, which represent a rate of $39 \%$. These results are in line with the results obtained by [5].

\subsubsection{Depending on habitat}

The study population is divided between cities (42\%), villages (38\%), douars (15\%) and nomads (5\%).

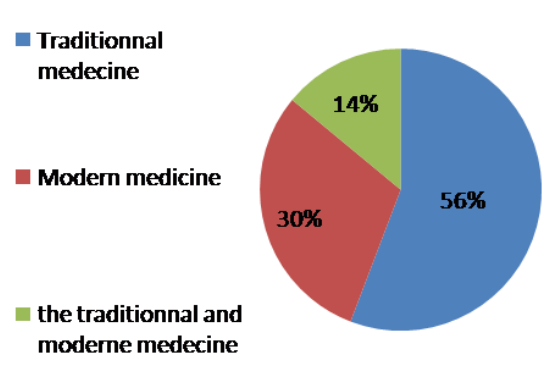

A

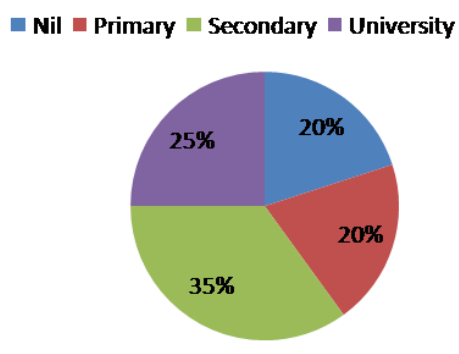

D

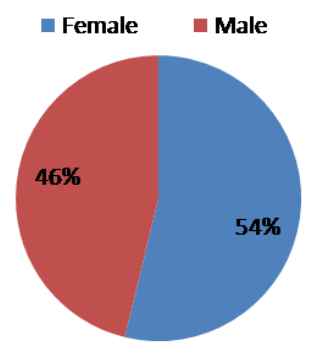

B

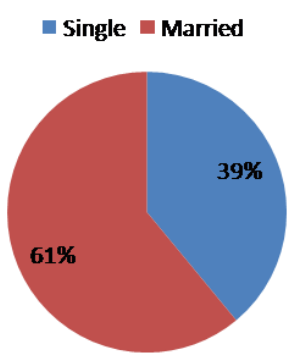

$\mathrm{E}$

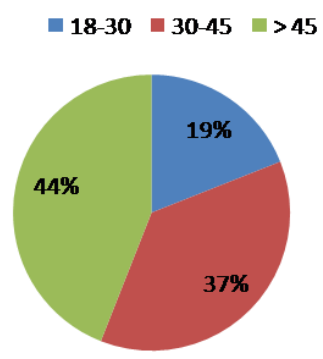

C

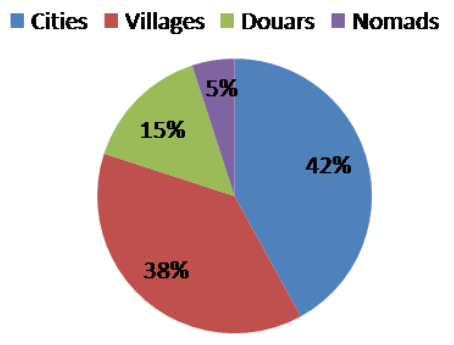

$\mathrm{F}$

Figure 2 Informant profile results (A- users of traditional medicine and modern medicine, B-Gender, C-Age, DEducation, E-Marital status, F-Habitat)

\subsubsection{The use of medicinal plants according to their use}

The majority of the people questioned use medicinal plants for their therapeutic use with a rate of $84 \%$. The cosmetic use occupies the second place with a rate of $16 \%$.

\subsubsection{The use of medicinal plants according to the parts used}

Various organs of plants are used by the population to satisfy their therapeutic needs, ranging from leaves, stems, fruits, roots, to barks, flowers or inflorescences, and sometimes even the entire plant. 
The percentage utilization of these different parts shows that leaves and seeds are most commonly used with a rate of $(51 \%-20 \%)$, followed by rhizomes and fruits with a similar rate of (7\%), followed by bark and flowers with a similar rate of (5\%), then the whole plant and stem with a similar p level of (2\%) and ultimately the bulbs with a rate of (1\%).

The leaves are the most widely used plant parts in the Arzew-Oran region, and the same results are obtained by [5]. The leaves are the site of photosynthesis and sometimes the storage of responsible secondary metabolites of the biological properties of the plant [6].

\subsubsection{According to the method of preparation}

Different therapeutic practices are used by the population to know the decoction, the infusion, the poultice, raw and cooked. Decoction, infusion are the most used modes with a percentage of $47 \%$, $24 \%$ Following the vintage, poultice, cooked and other preparations with percentages of $15 \%, 8 \%, 5 \%$ and $1 \%$ respectively.

\subsubsection{Depending on the dose used}

The $48 \%$ of users of medicinal plants prefer the spoon, others use the hand (36\%) and $11.00 \%$ use pinch and $5 \%$ use other doses. The dose remains random and linked according to the part of the plants.

\subsubsection{Distribution of users of medicinal plants according to the mode of possession of the information}

The $23 \%$ of the population refer to herbalists and $13 \%$ refer to themselves either by consulting the books of traditional Arab medicine or by following television programs or based on the experience of $61 \%$ due to the existence of many medicinal plants in their environment and 3\% people refer to the doctor.

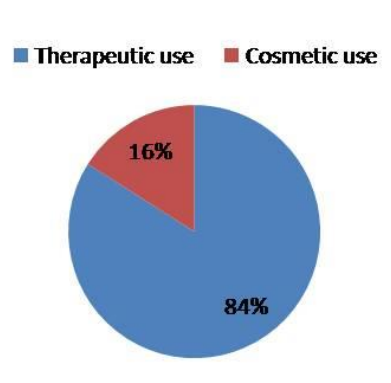

A

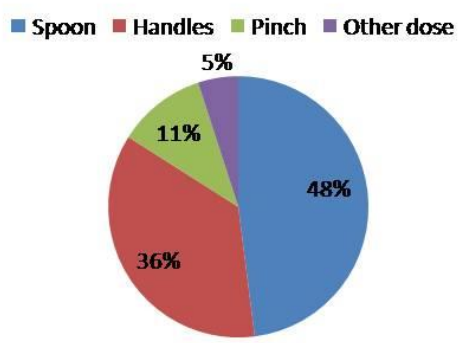

D

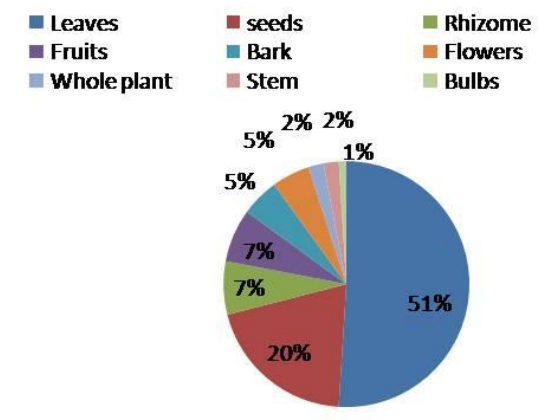

B

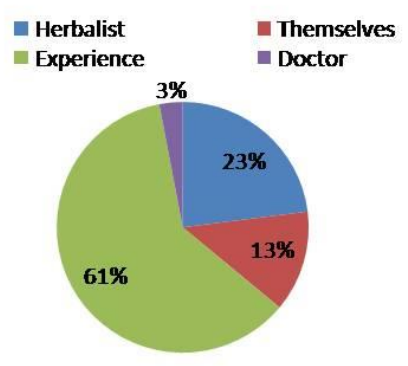

$E$

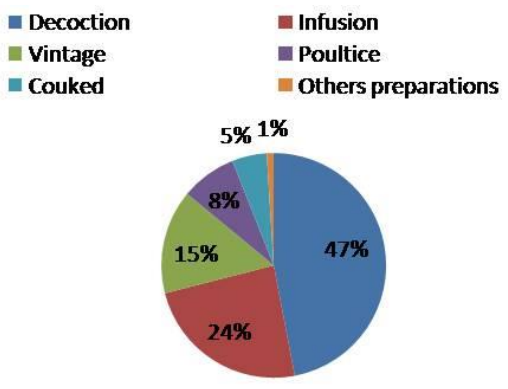

C

Healing Improvement $=$ Inefective

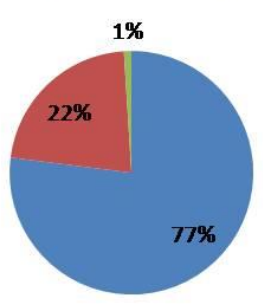

$\mathrm{F}$

Figure 3 Results of using medicinal plants (A- the use of the plant, B- the part of plant used, C- the method of preparation, D- the dose used, E- possession of information, F- effectiveness)

\subsubsection{Depending on therapeutic care}

The 77\% of people in Arzew believe that medicinal plants can heal treated diseases, $22 \%$ believe that medicinal plants only allow an improvement in health status. Nevertheless $1 \%$ of the population believes that medicinal plants cause side effects. 


\subsection{Floristic analysis}

On the basis of 500 questionnaires carried out in the Cercle d'Arzew (Oran), an ethnofloristic catalog was drawn up. The medicinal plants which are usually used by the population of Arzew (Oran) were identified and listed in Table 01. This data was used to carry out floristic study [7]. The floristic analysis of the listed species shows that 65 species are used. They are divided into 32 botanical families (Table 1). Among which three are the most dominant, in particular the Lamiaceae, the Apiaceae and the Fabaceae.

Table 1 Main medicinal plants used by the population of Arzew Circle (Oran)

\begin{tabular}{|c|c|c|c|}
\hline Family & Scientific name & Common name & Percentage (\%) \\
\hline \multirow[t]{6}{*}{ Apiacées } & Foeniculum vulgare & Fenouil & \multirow[t]{6}{*}{10.00} \\
\hline & Cuminum cyminum & Cumin & \\
\hline & Daucus carota & Carotte & \\
\hline & Pinpinella anisum & Anis vert & \\
\hline & Apium graveolens & Céleri & \\
\hline & Petroselinum sativum & Persil & \\
\hline Arécacées & Phoenix dactylifera & Palmier dattier & 0.60 \\
\hline Aristolochiacées & Aristolochia baetica & Aristoloche & 1.00 \\
\hline \multirow[b]{4}{*}{ Asteracées } & Inula viscosa & Inule visqueuse & \multirow{4}{*}{3.00} \\
\hline & Artemisia herba-alba & Armoise blanche & \\
\hline & Chamaemelum nobile & Camomille & \\
\hline & Cynara cardunculus & Cardon & \\
\hline \multirow[t]{3}{*}{ Brassicacées } & Sinapis alba & Moutarde blanche & \multirow[t]{3}{*}{1.80} \\
\hline & Brassica rapa & Navet & \\
\hline & Lepidium sativum & Cresson alénois & \\
\hline Cactacées & Opuntia ficus-indica & Figuier de Barbarie & 1.60 \\
\hline Chenopodiacées & Atriplex halimus & Pourpier de mer & 2.60 \\
\hline Cupressaceae & Jumperus communis & Genévrier & 1.00 \\
\hline Curcurbitacées & Cucumis sativus & Concombre & 0.80 \\
\hline \multirow{7}{*}{ Fabacées } & Trigonella foenum & Fenugrec & \multirow{7}{*}{7.0} \\
\hline & Vicia faba & Fève & \\
\hline & Lens exulenta & Lentille & \\
\hline & Ceratonia siliqua & Caroubier & \\
\hline & Glycyrrhiza glabra & Régless & \\
\hline & Glycine max & Soja & \\
\hline & Cassia senna & Séné & \\
\hline Hippoctanacées & Aexulus hippocasnum & Marronnier d'inde & 0.60 \\
\hline Ililiacées & Lllicium verum & Badiane chinoise & 1.00 \\
\hline Iridacées & Crocus sativus & Safran & 0.40 \\
\hline Labiacées & Ocicum basilicum & Basilic & 2.00 \\
\hline
\end{tabular}


Bouredja et al. / GSC Biological and Pharmaceutical Sciences 2017, 01(02), 041-048

\begin{tabular}{|c|c|c|c|}
\hline \multirow[t]{7}{*}{ Lamiacées } & Lavandula officinalis & Lavande & \multirow{7}{*}{29.0} \\
\hline & Mentha pulegium & Menthe pouliot & \\
\hline & Thymus vulgaris & Thym & \\
\hline & Melissa officinalis & Mélisse & \\
\hline & Salvia officinalis & Sauge & \\
\hline & Rosmarimus officinalis & Romarin & \\
\hline & Mentha spicata & Menthe & \\
\hline \multirow[t]{2}{*}{ Lauracées } & Cinnamonum laureiri & Cannelle & \multirow{2}{*}{2.40} \\
\hline & Laurus mobilis & Laurier & \\
\hline \multirow[t]{2}{*}{ Liliacées } & Allium sativum & Ail & \multirow{2}{*}{4.00} \\
\hline & Allium сера & Oignon & \\
\hline Linacées & Linum usitatissimum & Graine de lin & 1.20 \\
\hline \multirow[t]{2}{*}{ Lythracées } & Punica granatum & Grenadier & \multirow[t]{2}{*}{1.80} \\
\hline & Lawsonia inermis & Hénné & \\
\hline Myrtacées & Eucalyptus globulus & Eucalyptus & 2.00 \\
\hline \multirow{3}{*}{ Myristicacées } & Myrtus communis & Myrte & \multirow{3}{*}{1.40} \\
\hline & Eugenia caryophyllata & Clou de girofle & \\
\hline & Myristica fragrans & Noix de muscade & \\
\hline Oléacées & Olea europaea & Olive & 1.00 \\
\hline Pédaliacées & Sesamum indicum & Sésame & 1.40 \\
\hline Poacées & Vulgare hordeum & Orge & 0.80 \\
\hline Ranunculacées & Nigella sativa & Nigelle & 1.20 \\
\hline \multirow{2}{*}{ Rosacées } & Prunus domestica & Prune & \multirow[b]{2}{*}{1.40} \\
\hline & Prunus avium & Cerise & \\
\hline Rubicées & Coffea arabica & Café & 1.00 \\
\hline \multirow{3}{*}{ Rutacées } & Ruta montana & La rue & \multirow{3}{*}{3.20} \\
\hline & Citrus limon & Citron & \\
\hline & citrus aurantium & Orange & \\
\hline \multirow[t]{3}{*}{ Solanacées } & Solanum tuberosum & Pomme de terre & \multirow{3}{*}{0.80} \\
\hline & Capsicum frutescens & Le petit piment & \\
\hline & Solanum lycopersicum & Tomate & \\
\hline Urticacées & Urtica dioica & Ortie & 0.60 \\
\hline Verbénacées & Verbena officinalis & Verveine & 5.00 \\
\hline \multirow[t]{2}{*}{ Zingibéracées } & Eletteria cardamomum & Cardamome & \multirow[t]{2}{*}{6.00} \\
\hline & Zingiber officinale & Gingembre & \\
\hline
\end{tabular}




\subsubsection{Grouping of plant species used in the treatment of diseases affecting the respiratory system}

Results from data processing have shown that the most commonly used species in the treatment of diseases of the respiratory tract have been tabulated.

Table 2 Medicinal plants most commonly used in respiratory care

\begin{tabular}{lc}
\hline Plant species & Frequency of use \\
\hline Verbena officinalis & 30 \\
Thymus vulgaris & 20 \\
Mentha spicata & 22 \\
Eucalyptus globulus & 18 \\
Citrus limon & 14 \\
Mentha pulegium & 10 \\
Salvia officinalis & 9 \\
Lavandula officinalis & 8 \\
Rosmarimus officinalis & 5 \\
Glycyrrhiza glabra & 4 \\
\hline
\end{tabular}

Among the species most commonly used in respiratory disease treatments is the massive use of Verbena officinalis for its phytotherapeutic properties, namely influenza, colds, coughs and lung diseases. It is also considered as a plant par excellence of the diseases of the winter that is to say the chills of all kinds. It is a species found everywhere in Algeria, especially in damp places.

Given the proximity of the Arzew region to the Mediterranean Sea, the local population is more active in using plant species that treat diseases affecting the respiratory system. This is confirmed by the frequencies of use obtained by processing data from plant species such as Thymus vulgaris, and Eucalyptus globulus (Table 2).

\section{Conclusion}

The importance of medicinal plants is increasing in relation, in part, to the sharp increase in global demand in the last decades for medicinal plants and their products with the increasing number of users and the diversity of areas of their valorisation. The ethnobotanical study carried out in the region of Arzew enabled us to highlight the important place of traditional herbal medicine. The information obtained from the questionnaires and the floristic analysis carried out on the ground helped us to identify 65 species belonging to 32 families, the most frequently mentioned being Lamiaceae, Apiaceae and Fabaceae. The leaves are the most used part with a percentage of (51\%). Preparation in decoction is the most common galenic form. Similarly, on all the diseases treated, respiratory diseases represent the most cited diseases (40\%). In addition, this study allowed to appreciate and to know the traditional practices used by the population of the region of Arzew. The preparation in decoction is the most practiced mode with a percentage of $(47.00 \%)$. This study of medicinal flora aims at the valorisation and promotion of this cultural heritage which will ultimately enhance biodiversity and contribute to the development and well-being of the local population. This study constitutes an important database for the valorization of medicinal plants and the determining the health profile of local populations. The use of medicinal plants encourages researchers to exploring this path for the discovery of new biological molecules.

Finally, in spite of the medicines and the chemical arsenal of modern medicine, local communities in the Arzew region are still involved in the preservation of traditional know-how in traditional herbal medicine. This popular knowledge, considered as a legacy, can provide a platform for the exchange of experiences, knowledge and information concerning the traditional use of medicinal plants. 


\section{Compliance with ethical standards}

\section{Acknowledgments}

We would like to thank all the people of Arzew who kindly participated in our survey.

\section{Disclosure of conflict of interest}

The authors have no conflict of interest to declare.

\section{References}

[1] Ahmed, AA, Abou El-Ela, M, Jakupovic J, Seif El-Din AA and Sabri, N. (1990). Phytochemistry, 29, 3661-3663.

[2] Gomes C, Lourenc ELB, Liuti EB, Duque AO, Nihi F, Lourenc AC, Mendes TC, Junior AG and Dalsenter PR. (2012). Evaluation of subchronic toxicity of the hydroethanolic extract of Tropaeolum majus in Wistar rats. Journal of Ethnopharmacology, 142, 481-487.

[3] Pathak VP and Khanna RN. (1987). Sesquiterpene lactones from Artemisia maritima. Phytochemistry 26, 2103 2104.

[4] Salhi S, Fadli M, Zidane L and Douira A. (2010). Etudes floristique et ethnobotanique des plantes médicinales de la ville de Kénitra (Maroc). Lazaroa, 31, 133-146.

[5] Bouredja N, Messaoudi N and Benyamina K. (2017). Ethnobotanical and floristic study of medicinal plants in the region of Oued Tlelalt, Algeria. International Journal of Pharmaceutical Sciences and Research, 8(3), 11991204.

[6] Bigendako-Polygenis, MJ and Lejoly J. (1990). La pharmacopée traditionnelle au Burundi. Pesticides et médicaments en santé animale. Presses universitaires de Namur, 425-442.

[7] Eberhard T, Robert A and Annelise L. (2005). Plantes aromatiques : épices, aromates, condiments et huiles essentielles. édit la voisier, Paris, 522.

\section{How to cite this article}

Bouredja N, Mekdad H and Baghdadi K. (2017). Ethnobotany and floristic study of medicinal plants used in the treatment of respiratory diseases in the industrial region (Arzew) Oran, Algeria. GSC Biological and Pharmaceutical Sciences, 1(2), 41-48. 